\title{
RELATIONSHIP BETWEEN RAINFALL AND RUN-OFF IN THE STRATONI REGION (N. GREECE) AFTER THE STORM OF $10^{\text {th }}$ FEBRUARY 2010
}

\author{
SAPOUNTZIS M.* \\ STATHIS D.
}

Institute of Mountainous Water Management and Control Dept. of Forestry and Natural Environment

Aristotle University of Thessaloniki

P.O. Box: 268, 54124, Thessaloniki, Greece

Received: 20/09/2013

Accepted: 08/04/2014

Available online: 09/04/2014 *to whom all correspondence should be addressed: e-mail: sapuntzi@for.auth.gr

\begin{abstract}
Extreme floods often demonstrate unanticipated characteristics that pose problems for management and response. The flood in the Stratoni region in February 2010 provided an example of such unexpected response. The aim of this paper is the quantification of the hydrologic response of the torrents that outfall in the area of Stratoni of the prefecture of Chalkidiki by means of the synthetic unit hydrograph method. For this purpose, the effective rainfall is estimated with a Curve Number of Soil Conservation Service (SCS) procedure. In addition, the flood hydrograph is estimated using the Sierra Nevada's synthetic unit hydrograph procedure. The resulting maximum flood discharge was compared with the value obtained by the method of flood-water traces and found not to differ significantly. Understanding of the hydrological operation of floods in small watersheds helps towards the design of plans and constructions of the infrastructure against flood risk.
\end{abstract}

Key words: flood discharge, hydrograph, SCS method.

\section{Introduction}

Floods and the damage they cause are a global phenomenon and occur in many parts of the Earth with different frequency (Ahrens, 1994; Schilling, 1997; Dhar \& Nandargy, 2003). In addition to the natural disastrous events, floods are by far the most hazardous, frequent and widespread events throughout the world (Dhar and Nandargy, 2003). The mean annual precipitation in Northern Europe, based on observational data, increased by $10 \%-40 \%$ while it has decreased in some areas of Central Europe and the Mediterranean region by up to $20 \%$ over the last century (EEA, 2004). Particularly for the Mediterranean countries, the scarcity of water and floods occurs intensely within the last decades (Hisdal et al. 2001; Gaumea et al. 2004). Drought events in the Mediterranean have been more frequent after 1970 (Hisdal et al. 2001; Iglesias et al. 2007). However, great problems are caused by the water amounts running off as floods following an intense rainstorm. The climatic regime and the juxtaposition of highland produce a propensity towards extreme flooding in many areas of the Mediterranean (Hooke, 2006). Especially in Greece many areas often experience flood phenomena (Kotoulas, 1980a; Stefanidis, 1995a; Papamichail et al., 2001). Nowadays, human intervention is vast and often results, in intense flooding (Stefanidis, 1995a; Stathis et al., 2010). Even relatively low-intensity rainfall, when occurring in regions with highly disturbed watersheds and streams can be disastrous (Kotoulas, 1980a; Chow et. al., 1988). In order to avoid or reduce those flooding hazards and to construct flood-preventing infrastructure, it is considered essential that the maximum amount of the run-off water is estimated (Myronidis et al., 2010; Stathis et al., 2010). That attempt is of major importance in watersheds where 
the plain part of the stream passes through villages and the occurrence of a flood could threaten even human lives. Certainly, the rainfall height is the main factor in the case of floods, however human intervention, especially in the main streams of torrents, intensifies the outcome (Chow, 1964; Aulitzky 1985; Stefanidis and Kotoulas, 1992; Kotoulas 2001; Hooke, 2006, Fotakis et al., 2007; Myronidis et al., 2009). An important practical application of hydrology is the estimation of extreme rainfalls and flood events, because the planning and design of water resource projects and flood-plain management depend on the frequency and magnitude of peak discharges (Arthur and Cudworth, 1987; Chow et al., 1988; Shaw, 1993; Loukas et al., 1996). The estimation of the discharge caused by a particular rainfall is usually achieved by applying a unit hydrograph, which can be defined by studying the relationship between rainfall and run-off. Especially in small watersheds, where measurements of the discharge are not available, quantification of the hydrologic response is faced using the Synthetic Unit Hydrograph procedure (SUH). (SCS, 1972; Linsley et al., 1975; Arthur and Cudworth, 1987; USDI, 1987; Shaw, 1993; Jain et al., 2000; Daniil et al., 2005; Kumar et al., 2007). The distribution of precipitation in Greece is uneven in space and in time Sofios et al., 2008). This characteristic of Mediterranean climate causes great flood problems not only in regions with high average annual precipitation but also, in drier areas as is northern Greece (Stefanidis, 1995b; Stefanidis et al. 2007). This research aims at the investigation of the hydrological response of watersheds of the torrents in Stratoni village in Chalkidiki after the rainfall event of $10^{\text {th }}$ February 2010. Intense flooding phenomena caused severe damages. The objective of the research is expected to be achieved by employing the Sierra Nevada SUH method. The effective rainfall is estimated using the curve number of Soil Conservation Service (SCS) procedure. An understanding of the hydrological operation of streams in small watersheds helps towards the correct planning of areas liable to flooding, as well as in the design of plans for prediction and protection that are sufficiently flexible to allow rapid and effective response (Camarasa Belmonte and Segura Beltran, 2001). In Greece, there are more than a thousand disastrous torrents, for which there are no hydrometric measurements (a part from few exceptions) and therefore there is no hydrometric data (Stefanidis, 1995a; Kotoulas 2001). That is why use of the method of the synthetic unit hydrograph is considered essential. The flood hydrographs produced from the application of SUH of the region of Sierra Nevada for the Greek facts seem to illustrate sufficiently the course of the flood (Papamichail et al., 2001; Georgiou et al., 2003; Sapountzis et al., 2007). This method was applied in nearby regions but also, in watersheds in the wider Greek area (Papamichail et al., 2001; Stathis and Sapountzis 2003; Daniil et al., 2005; Sapountzis et al., 2007). In addition, Papamichail et al., (2001) and Stathis and Sapountzis (2003) concluded that the results of the Sierra Nevada method compared to the results stemming from the application of the method of the flood water traces do not differ significantly. An advantage of the method is that it was developed on data from a region with meditteranean climate (USDI 1987; Papamichail, 2001). A second advantage of this method is that the time step of the unit hydrograph is steady thus, allowing the augmentation of consecutive hydrographs (Papamichail, 2001). In addition, Sierra Nevada method predicts correctly the real time of the peak flood discharge (Georgiou et al., 2003).

\section{Study area and datasets}

The present research was conducted in N. Greece in Stratoni village where four streams which originating in the northwestern hills, cross over the homonymous settlement and discharge into the lerissos Gulf (Fig. 1). Physiographically, the study watersheds are comprised of dendritic form ephemeral streams developed on hilly and semi mountainous areas with significant main stream and catchments slopes despite their small size. The average altitude of the surfaces varies from $240 \mathrm{~m}$ to $360 \mathrm{~m}$ whereas their main geomorphologic elements are summarized in Table 1. The geology map of the study area was delineated from 1:50,000 scaled geology sheets of the Greek Institute of Geology and Mineral Exploration. Gneiss is the dominating rock formation in most of the watersheds with a cover ranging from 40 to $73 \%$ and is found mainly at higher altitudes. Granodiorite also occupies a considerable percentage in the study area which varies from 13 to $42 \%$. Finally, neogenic and alluvial formations are found only in watershed 1 while the presence of amphibolites is substantial only is sub-watershed 1a in 
Figure 1. The land use map of the study area was derived using the available orthophotos image of 1998 and was validated in the field with a MIO-P360 GPS. Forests of evergreen and deciduous broadleaved species constitute the main natural vegetation of the watersheds with a cover of more than $77 \%$ which provides efficient protection to the soil.
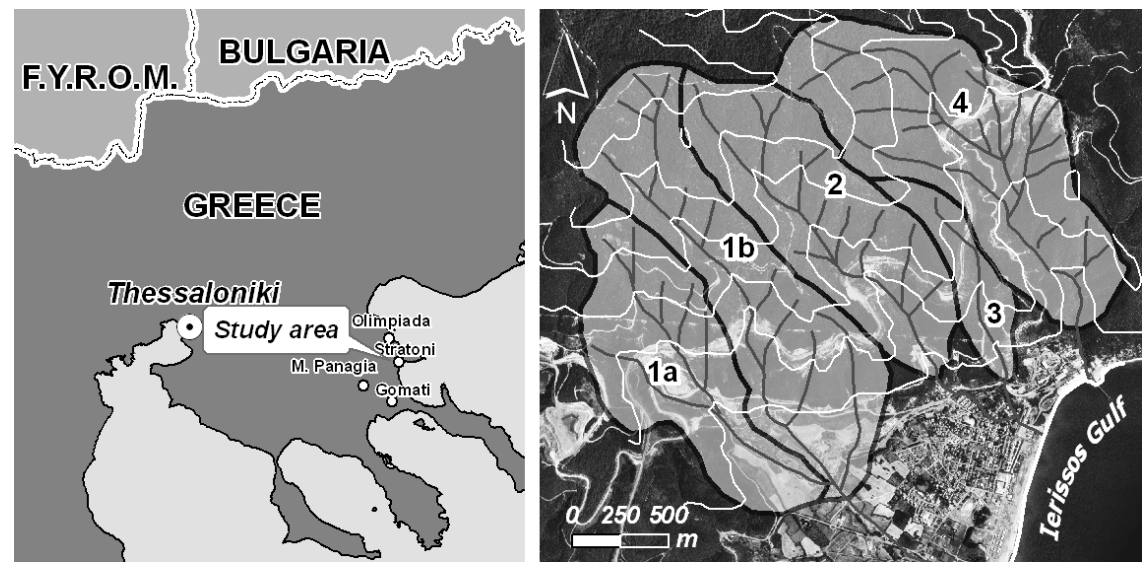

Figure 1. Location map of the study area

Table 1: The main physical characteristics of the study area catchments

\begin{tabular}{|c|c|c|c|c|c|c|c|c|c|c|}
\hline \multirow{3}{*}{\multicolumn{2}{|c|}{$\begin{array}{l}\text { Code/ } \\
\text { Name of torrent }\end{array}$}} & \multirow{4}{*}{$\begin{array}{c}\text { Area } \\
\mathrm{F} \\
\mathrm{km}^{2}\end{array}$} & \multirow{4}{*}{$\begin{array}{c}\begin{array}{c}\text { Peri- } \\
\text { meter }\end{array} \\
\mathrm{U} \\
\mathrm{km}\end{array}$} & \multicolumn{3}{|c|}{ Elevation } & \multirow[b]{2}{*}{$\begin{array}{l}\text { Mean } \\
\text { slope }\end{array}$} & \multirow[b]{2}{*}{ Dense } & \multicolumn{2}{|c|}{ Main stream } \\
\hline & & & & Min & Max & Mean & & & \multirow{3}{*}{$\begin{array}{c}\text { Length } \\
\mathrm{L} \\
\mathrm{km}\end{array}$} & \multirow{3}{*}{$\begin{array}{c}\begin{array}{c}\text { Mean } \\
\text { slope }\end{array} \\
\begin{array}{c}J_{L} \\
\%\end{array}\end{array}$} \\
\hline & & & & $\mathrm{Hmin}$ & Hmax & Hmed & $J_{1}$ & D & & \\
\hline & & & & $\mathrm{m}$ & $\mathrm{m}$ & $\mathrm{m}$ & $\%$ & $\mathrm{~km} / \mathrm{km}^{2}$ & & \\
\hline \multicolumn{2}{|r|}{ (1) } & (2) & (3) & (4) & (5) & (6) & (7) & (8) & (9) & (10) \\
\hline 1 & Karbounoskala & 2.15 & 6.62 & 30.0 & 690.0 & 311.7 & 45.2 & 4.66 & 2.60 & 24.80 \\
\hline $1 a$ & Subwatershed & 0.90 & 4.68 & 40.0 & 560.0 & 249.6 & 42.3 & 4.31 & 1.77 & 24.00 \\
\hline $1 b$ & Subwatershed & 1.25 & 6.11 & 40.0 & 690.0 & 351.6 & 47.3 & 4.92 & 2.60 & 24.80 \\
\hline 2 & Argiro & 1.05 & 4.85 & 60.0 & 650.0 & 363.6 & 54.8 & 4.93 & 2.15 & 26.90 \\
\hline 3 & Anonymo & 0.26 & 2.88 & 60.0 & 460.0 & 238.5 & 50.8 & 4.19 & 1.08 & 27.70 \\
\hline 4 & Porto & 1.37 & 5.49 & 40.0 & 610.0 & 304.7 & 49.3 & 6.11 & 2.54 & 21.20 \\
\hline
\end{tabular}

In the Stratoni Port a meteorological station which belongs to the National Observatory of Athens (NOA) has been operating since the end of 2009. This station recorded the storm event under investigation. However, the long term precipitation analysis was carried out on the basis of the information of the state rain gauge located in M. Panagia with 30-year-records of annual precipitation data (Fig. 1). The general climate of the region is typical thermo-Mediterranean with mean annual precipitation of 598.5 $\mathrm{mm}$. More than $45 \%$ of the annual rainfall occurs during winter while the rainiest month is December. In should be marked that, in the surrounding area (Olympiada, Stratoni, M. Panagia, Gomati), in a distance less than $15 \mathrm{~km}$ (Fig. 1), four extreme rainfall events have been recorded during the last decade with a $24 \mathrm{~h}$ total rainfall amount that ranges from 111 to $236 \mathrm{~mm}$ and maximum hourly intensities that vary from 20 to $47 \mathrm{~mm}$.

\section{Materials and methods}

\subsection{Characteristics of the rainfall of the $10^{\text {th }}$ February 2010}

During the period, $6^{\text {th }}-10^{\text {th }}$ February, in the study area, there were reports of continuous rainfalls which on the 10th February reached a peak resulting in intense flooding in the settlements of Stratoni, Gomati and the second peninsula of Chalkidiki, Sithonia (Fig.1). On $6^{\text {th }}$ February rainfall reached $93.8 \mathrm{~mm}$ and on 
$10^{\text {th }}$ February $163.6 \mathrm{~mm}$, with $112 \mathrm{~mm}$ in 6hours. The hourly distribution of the rain incident for the port station is illustrated in Figure 2. The rainfall started during the morning hours on $10^{\text {th }}$ February with low intensity. At 9:30 the intensity rose to $5 \mathrm{~mm} \cdot \mathrm{h}^{-1}$ and at $12: 30$ rose again to $10 \mathrm{~mm} \cdot \mathrm{h}^{-1}$. The phenomenon continued with steady intensity for four hours. At 16:30 the rainfall peaked for a period of three hours with a total height of $80.4 \mathrm{~mm}$ and maximum hourly intensity $43 \mathrm{~mm} \cdot \mathrm{h}^{-1}$. According to the residents, the flooding incident occurred at 18:30. Till midnight another $14.2 \mathrm{~mm}$ fell over.

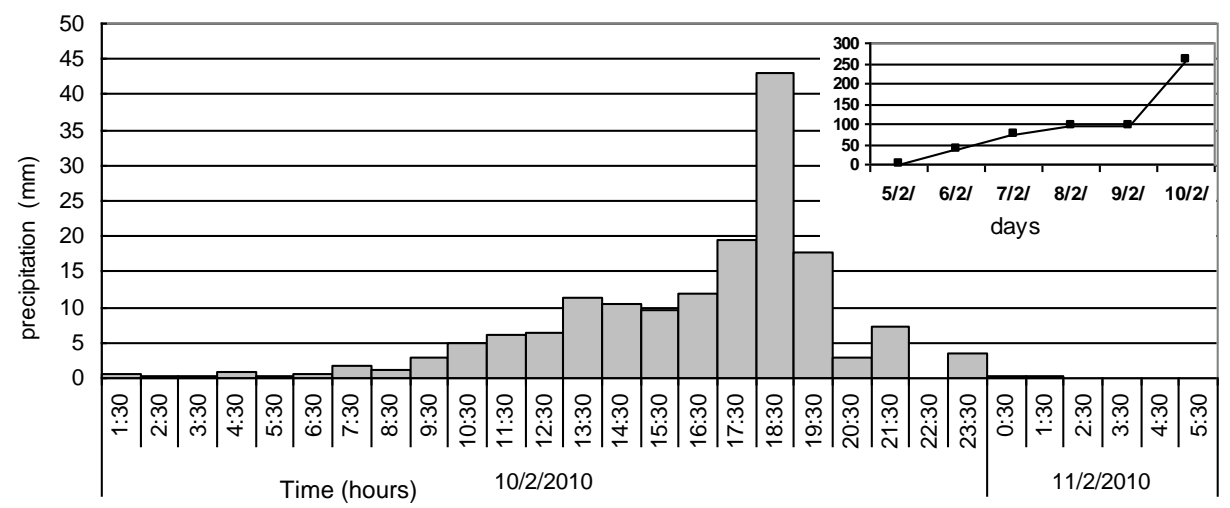

Figure 2. Hourly distribution and total amount of the rainfall in the Stratoni Station

The curve of intensity-duration-frequency studied at the station of Megali Panagia, which is approximate to the area, is given by the equation (Georgiou et al., 2003):

$\mathrm{i}=\frac{20.5069 \times \mathrm{T}^{0.1613}}{\mathrm{t}^{0.64}}$

where: $\mathrm{i}=$ intensity $\left(\mathrm{mmh}^{-1}\right), \mathrm{T}=$ return period (years) and $\mathrm{t}=$ duration of rainfall (hours)

The return period for the rainfalls 6 hours, 3 hours and 1hour duration for the specific incident, as it derives from the equation (1), is approximately 700 years, 410 years and 100 years respectively. From the above, it is evident that the rainfall of $10^{\text {th }}$ February was torrential and with an especially long return period. At this point, it should be stressed that the accurate determination of the return period of rainfalls requires a curve of the above form for the same station. The structure of this curve calls for adequate data, which was not available. It should be noticed that the total rainfall $(257.2 \mathrm{~mm})$ of those five days corresponded to more than $40 \%$ of the mean annual rainfall of the region.

\subsection{Effective rainfall and flood hydrograph}

The estimation of the flood hydrograph for the rainfall of the $10^{\text {th }}$ February 2010 was conducted by determining the effective rainfall of the method of the runoff curve number of the SCS and the Synthetic Unit Hydrograph of Sierra Nevada procedure, as given in "Design of Small Dams" (USDI, 1987). The method of the Runoff Curve Number (CN) of the SCS (1972) is a widely used method for the estimation of the discharge after a rainfall in watersheds without hydrometric data (Chow, 1964; Linsley et al., 1975; U.S.D.I., 1987; Tsakiris, 1995; Stathis et al., 2010).

The estimation of the rainfall loss is produced by applying the Runoff Curve Number of the SCS. The mathematical model for the effective rainfall according to SCS is the following:

$P_{e}=\frac{(P-I)^{2}}{(P-I)+S}$

where $P>1$

$S=254 \times\left(\frac{100}{C N}-1\right)$ 
Where, $\mathrm{P}_{\mathrm{e}}$ : Cumulative Effective Rainfall $(\mathrm{mm}), \mathrm{P}$ : Cumulative Storm rainfall of the watershed $(\mathrm{mm})$, I: Initial abstraction (shortage) consisting mainly of interception, infiltration and surface storage $(\mathrm{mm})$, $\mathrm{S}$ : Potential maximum watershed storage parameter $(\mathrm{mm}), \mathrm{CN}$ : Runoff Curve Number which is determined by the morphometric, hydrographic and soil characteristics as well as by the vegetation type in the watershed.

In cases where initial abstraction (I) is not known, it can be calculated as follows:

$\mathrm{I}=0.2 \times \mathrm{S}$

From the equations (2) and (3) it can be seen that the effective rainfall is dependent only on $\mathrm{CN}$, given that $P$ is known and $I$ is either known or can be found from the equation (4). The Runoff Curve Number is dependent on the land management, the penetration ability of the soil and the previous water condition of the soil. The $\mathrm{CN}$ values are given in tables in relation to the above factors.

According to the Sierra Nevada Synthetic Unit Hydrograph (SUH) method, the lag time (in hours) of the S.U.H. is estimated by the following equation:

$\operatorname{Lg}=0.1776 \times C \times\left(\frac{\operatorname{Lx} \mathrm{LC}}{\sqrt{S}}\right)^{0.33}$

Where, 0.1776: coefficient modifying in units of I.S., Lg: Lag Time of the SUH (hours), C: Constant, additional analyses have led investigators to conclude that $C$ should be 26 times the average Manning's $\mathrm{n}$ value representing the hydraulic characteristics of the drainage network (Arthur and Cudworth, 1987; USDI, 1987). This average Manning's $n$ value is identified as $\mathrm{Kn}$. Thus, $\mathrm{C}=26 \cdot \mathrm{Kn}$ (for the research area $\mathrm{Kn}=0.12$ ). Application shows that a satisfactory value of $\mathrm{Kn}$ can be established for ungaged basins during a field reconnaissance by the more experienced flood hydrologist (Arthur and Cudworth, 1987), L: Length of the main stream $(\mathrm{km})$, Lc: Length along the main stream from the point of concentration to a point opposite to the centroid of the drainage basin $(\mathrm{km})$, S: Slope of the main stream $\left(\mathrm{m} \mathrm{m}^{-1}\right)$

The duration of the unit rainfall $D$ (in hours), from which the SUH is derived, is given by the equation:

$D=\frac{\operatorname{Lg}}{5.50}$

The dimensionless unit hydrograph of Sierra Nevada, according to the "Design of Small Dams", is given in Figure 3. The dimensionless time $(\mathrm{T})$ is expressed in function of time in percent of lag time $(\mathrm{Lg})$ and the semiduration $(D / 2)$ of unit rainfall on the abscissa scale. The ordinate values of discharge (q) are determined by lag time $(\mathrm{Lg})$, the semiduration $(\mathrm{D} / 2)$ of unit rainfall and the volume of $1 \mathrm{~mm}$ of runoff from the subject basin (Muzik, 1992).

The following procedure was applied for the calculation of the SUH caused by an effective rainfall of 1 $\mathrm{mm}$ :

- the values of time in the SUH graph are found by the following equation:

$\mathrm{t}_{\mathrm{m}}=\frac{\mathrm{T}}{100} \times\left(\mathrm{Lg}+\frac{\mathrm{D}}{2}\right)$

where, $t_{m}$ : time value in the SUH (hours), T: dimensionless time (values given in tables of USDI, 1987), Lg: lag time of the SUH (hours) (equation 5), D: duration of the unit rainfall (hours) (equation 6)

- the discharge values in the S.U.H. are found by using the equation:

$Q=0.01157 \times\left[\frac{A \times q}{\left(L_{g}+\frac{D}{2}\right)}\right]$

where Q: discharge of the SUH $\left(\mathrm{m}^{3} \mathrm{sec}^{-1}\right)$, A: surface of the watershed $\left(\mathrm{km}^{2}\right)$ and $\mathrm{q}$ : dimensionless discharge (values given in tables of USDI, 1987) 


\section{4. $\quad$ Results}

The effective rainfall was estimated based on the hyetograph of the Stratoni station, which is located within the study area. The Rainfall Curve Number for soil water condition of Type II, and for that particular area, was found equal to 71.8 and the parameter $\mathrm{S}$ was found equal to $100 \mathrm{~mm}$, while the rain loss was $20 \mathrm{~mm}$. This value cannot be justified by the forest coverage and the other features of the watershed.

However, we took them into account, because the storage capacity of the soil was limited because of the rainfalls of previous days. Due to the above reasons, the rain loss (I) and the storage capacity (S) were re-estimated for antecedent soil moisture condition III.

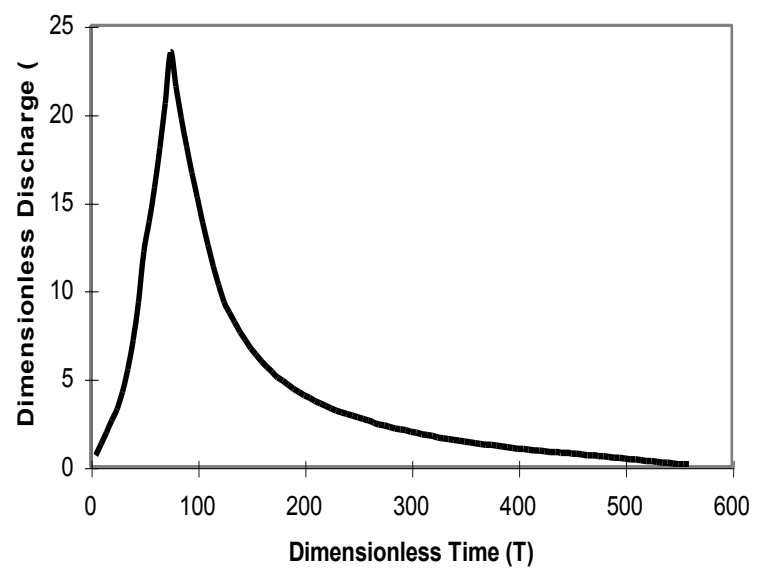

Figure 3. Dimensionless Unit Hydrograph of Sierra Nevada

In Table 2 the results of this work are presented. With the help of these values and equation (2), the excess rainfall for every watershed was estimated. The 10 minute distribution of rainfall and the respective effective rainfall for the watershed Argiro (2) are shown in Figure 4. The lag time of the unit hydrograph for the watersheds, the duration of the unit rainfall and the equations for the time and discharge of the SUH are presented in Table 3. In accordance to the above methodology, the SUH of each watershed was modified based on the principle of superposition and proportionality and was calculated for a duration: $D_{1}=1$ hour for the sub-watersheds of Karbounoskala, $D_{2}=20$ minutes for the watershed Argiro and $\mathrm{D}_{3,4}=10$ minutes for the watersheds Anonimo and Porto (Fig. 5).

The hydrograph of the flood was drawn based on the Synthetic Unit Hydrograph of the watersheds and the corresponding effective rainfall (Fig. 6). The baseflow during the storm was considered as negligible and the peak-discharge for the watershed 2, Argiro reached a value of $10.47 \mathrm{~m}^{3} \mathrm{~s}^{-1}$ and the total volume of water $128,000 \mathrm{~m}^{3}$. In addition, the peak-discharge was found with the method of flooding flood-water traces, based on the geometrical features of the cross-section of the main stream, the slope and the roughness of the torrent- bed and then, by applying the Manning-Strickler equation. The method involves a linear streambed, a fixed cross section and roughness, on a large length. These conditions are validated only in the streambed of torrent Karbounoskala where they were applied. The rest of the torrential streams overflowed during the flood because of the intense sedimentation and the narrows of the streambed in the settlement. The cross-section is shown in Figure 7 and the results from the application of the above method are presented in table 4 .

The peak-discharge value appearing in Table 4, was calculated as $Q \max =21.9 \mathrm{~m}^{3} \cdot \mathrm{sec}^{-1}$. However, the value $Q$ max $=17.98 \mathrm{~m}^{3} \mathrm{sec}^{-1}$ emerged from the application of the method of the hydrograph. So the values of the peak-discharge found by means of two methods did not differ significantly. 
The runoff coefficient which is dimensionless was calculated as the ratio of runoff depth to the total precipitation based on the SCS-CN method. The runoff coefficient raised to 0.75 for the Argyro's watershed (Fig. 8).

From the four torrential currents the most serious problem was caused by Argyro torrent which also developed the debris flow. Despite the fact that the watershed is only $F=1,05 \mathrm{~km}^{2}$ and it is fully covered by forest, it combines the two basic characteristics which a torrent must have in order to develop the debris flow phenomenon. These are: a necessary least inclination of stream bed (gradient:13 ${ }^{\circ}$ ) and a sufficiently big growth available of the materials brought (accumulation of the materials in large amounts in the main stream as much as in the eroded sidewalls) (Kotoulas,1980b, 2001). In this case there was also the generative cause, the rare rainfall in height and in intensity which resulted in the deterioration of the catastrophic flood (Fig. 9).

Table 2. $\mathrm{CN}$ values for the watersheds

\begin{tabular}{cccccccc}
\hline \multirow{2}{*}{ Code } & \multirow{3}{*}{ Name of torrent } & \multicolumn{3}{c}{$\begin{array}{c}\text { Antecedent soil moisture } \\
\text { condition type II }\end{array}$} & \multicolumn{3}{c}{$\begin{array}{c}\text { Antecedent soil moisture } \\
\text { condition type III }\end{array}$} \\
\cline { 3 - 7 } & & $\mathrm{CN}_{\text {II }}$ & $\mathrm{S}$ & $\mathrm{I}$ & $\mathrm{CN}_{\text {III }}$ & $\mathrm{S}$ & $\mathrm{I}$ \\
\hline & & & $(\mathrm{mm})$ & $(\mathrm{mm})$ & & $(\mathrm{mm})$ & $(\mathrm{mm})$ \\
\hline 1 & Karbounoskala & 73.0 & 94.0 & 18.8 & 87.5 & 36.3 & 7.2 \\
\hline $1 \mathrm{a}$ & Subwatershed & 73.0 & 94.0 & 18.8 & 87.5 & 36.3 & 7.2 \\
\hline $1 \mathrm{~b}$ & Subwatershed & 73.0 & 94.0 & 18.8 & 87.5 & 36.3 & 7.2 \\
\hline 2 & Argiro & 70.6 & 105.8 & 21.2 & 86.1 & 41.0 & 8.2 \\
\hline 3 & Anonymo & 70.0 & 108.8 & 21.8 & 85.7 & 42.0 & 8.5 \\
\hline 4 & Porto & 71.2 & 103.0 & 20.6 & 86.4 & 40.0 & 8.0 \\
\hline
\end{tabular}

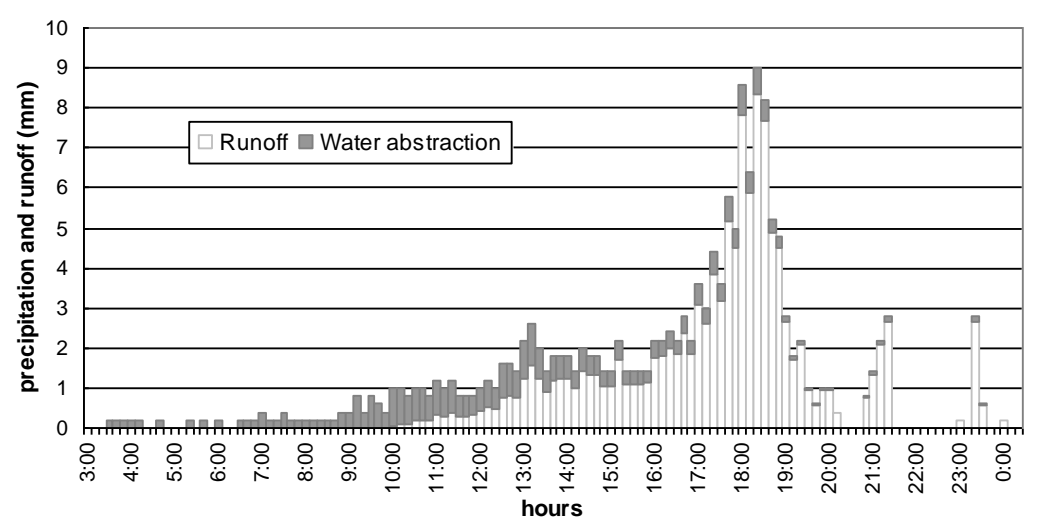

Figure 4. Distribution of the effective rainfall in a ten-minute period for the torrent 2

Table 3. Parameters of the Synthetic Unit Hydrographs

\begin{tabular}{cccccc}
\hline Code & Name of torrent & $\begin{array}{c}\text { Lag time } \\
\text { Lg }\end{array}$ & $\begin{array}{c}\text { Duration SUH } \\
\text { D }\end{array}$ & $\begin{array}{c}\text { Time of the } \\
\text { SUH } \\
\text { tm }\end{array}$ & $\begin{array}{c}\text { Discharge of the } \\
\text { SUH } \\
\text { Q }\end{array}$ \\
\hline & & (hours) & (hours) & (hours) & $\left(\mathrm{m}^{3} \mathrm{~s}^{-1}\right)$ \\
\hline 1 & Karbounoskala & 1.070 & 0.2000 & $0.0117 \mathrm{~T}$ & $0.02130 \mathrm{q}$ \\
\hline $1 \mathrm{a}$ & Subwatershed & 0.655 & 0.1250 & $0.0098 \mathrm{~T}$ & $0.01083 \mathrm{q}$ \\
\hline $1 \mathrm{~b}$ & Subwatershed & 0.850 & 0.1650 & $0.0093 \mathrm{~T}$ & $0.01526 \mathrm{q}$ \\
\hline 2 & Argiro & 0.620 & 0.1100 & $0.0068 \mathrm{~T}$ & $0.01791 \mathrm{q}$ \\
\hline 3 & Anonymo & 0.371 & 0.0833 & $0.0044 \mathrm{~T}$ & $0.00681 \mathrm{q}$ \\
\hline 4 & Porto & 0.900 & 0.1636 & $0.0099 \mathrm{~T}$ & $0.01644 \mathrm{q}$ \\
\hline
\end{tabular}




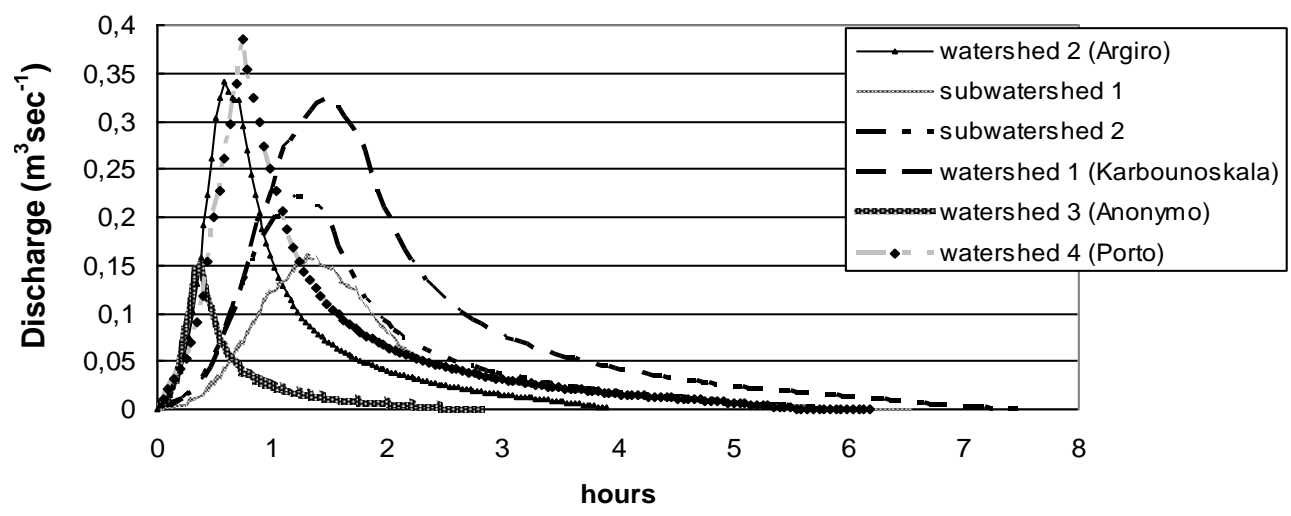

Figure 5. Synthetic Unit Hydrographs of the watersheds of the research area

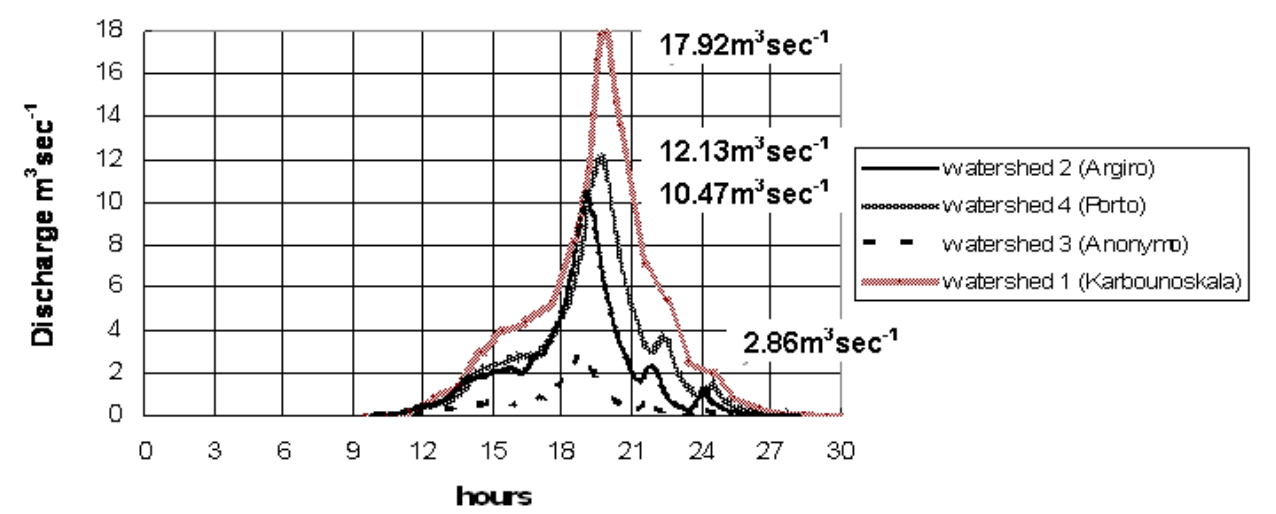

Figure 6. Hydrographs of the floods in the watersheds of the research area

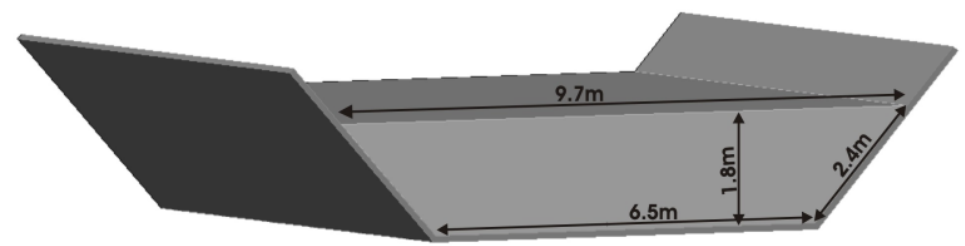

Figure 7. Cross-section $\mathrm{D}_{1}$, at the mainstream of the torrent Karbounoskala

Table 4. Hydrological characteristics and maximum peak-discharge

\begin{tabular}{ccccccc}
$\begin{array}{c}\text { Coefficient } \\
\text { roughness }\end{array}$ & Surface & $\begin{array}{c}\text { Perimeter } \\
\text { section }\end{array}$ & $\begin{array}{c}\text { Hydraulic } \\
\text { radius }\end{array}$ & $\begin{array}{c}\text { Stream } \\
\text { bed slope }\end{array}$ & $\begin{array}{c}\text { Average } \\
\text { velocity }\end{array}$ & Peak-discharge \\
\hline$(\mathrm{k})$ & $\mathrm{F}\left(\mathrm{m}^{2}\right)$ & $\mathrm{U}(\mathrm{m})$ & $\mathrm{R}=\mathrm{F} / \mathrm{U}(\mathrm{m})$ & $\mathrm{J}(\%)$ & $\mathrm{V}\left(\mathrm{m}^{-1}\right)$ & $\begin{array}{c}\mathrm{Qmax}^{1} \mathrm{~m}^{3} \mathrm{sec}^{-} \\
20\end{array}$ \\
14.6 & 11.3 & 1.29 & 0.4 & 1.50 & 21.90 \\
\hline
\end{tabular}




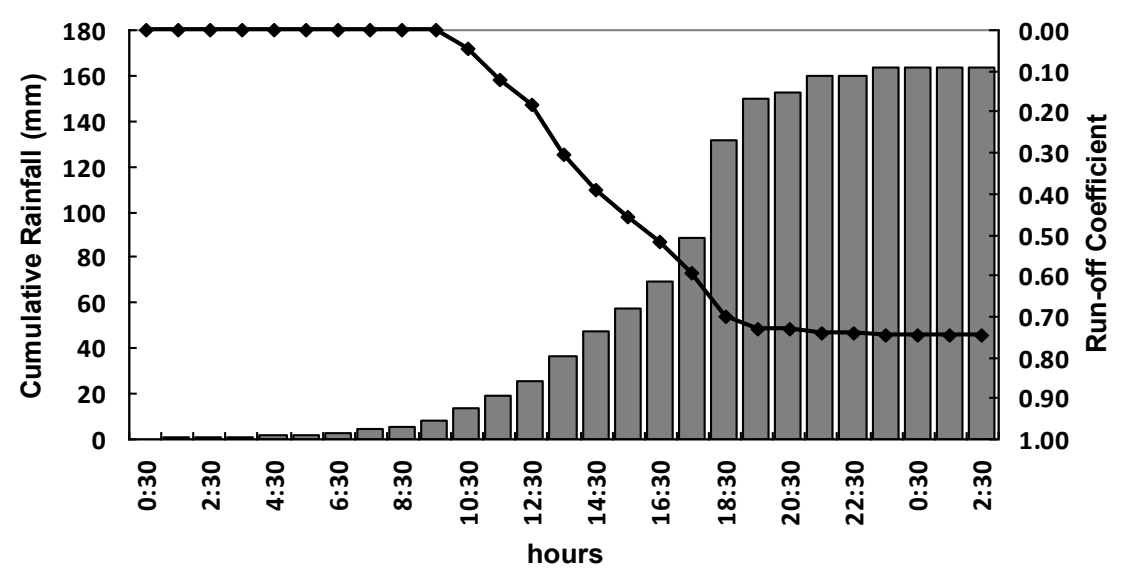

Figure 8. Instantaneous Runoff Coefficient and Cumulative Rainfall of the torrent Argiro

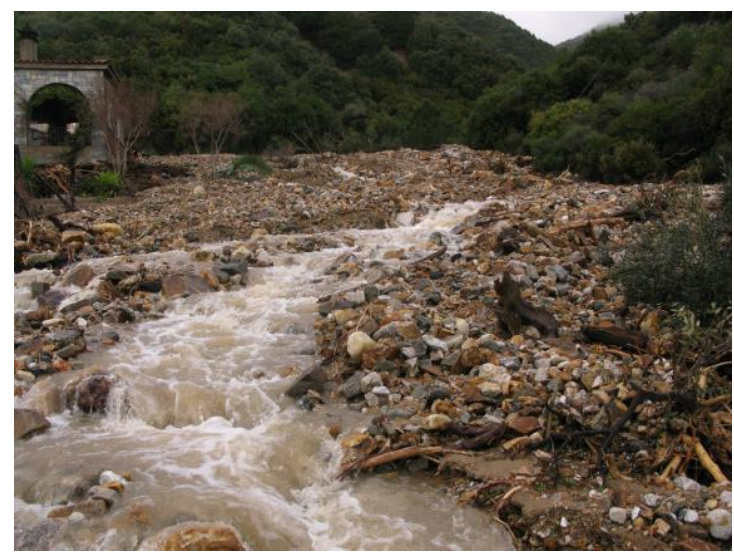

Figure 9. Debris flow disaster caused by torrent Argiro in Stratoni village

\section{Discussion}

The torrents of the area of Stratoni region belong to the category of hilly areas torrents and present a considerable percentage of forest coverage. These conditions contribute significantly to the smoothing of the flooding phenomena in the area following rainfalls of minor and medium intensity. In cases of rainfalls of considerable intensity, the protective role of the vegetation is restricted dramatically (White et al., 2007; Serrano-Muela et al., 2008). The forest's initial influence on a flood-producing rainstorm is the amount it intercepts and stores in the canopy. This interception, is a major influence only in the case of light showers; it is most effective durring brief storms, but its effectiveness dwindles rapidly as storm size increases" (Anderson et al., 1976). For a given region, peakflow rates are generally lower in watersheds with a greater percentage of forest coverage. Forest coverage can be effective to the flood control in a small watershed and for storms of low intensity and short duration. In general, case studies in southern China suggest that forests could reduce peakflows by $50 \%$ in watersheds of an area $<10 \mathrm{~km}^{2}$ (Qi et al., 2009). For instance, Hibbert (1971) and Scott and Lesch, (1997) reported that reforestation resulted in a reduction of low flows. Surely the forest coverage contributed, up to a point, to the suffering of the flood phenomenon from the moment that all the water holding surfaces were satiated with the available water, the contribution was stabilized. From this point further and as the rainfall continued the instantaneous runoff coefficient was increased constantly. From the diagram of the cumulative flow height of the rain and the instantaneous runoff coefficient for the Argyro's watershed (Fig.8) it is obvious that the size of the flow factor rises with the increase of total height of rain. This occurs because the water holding processes have an exceeded size. For example, in Argyro's watershed 
if the rainfall had stopped after six hours the runoff coefficient would have been 0.45 while in this case $\left(10^{\text {th }}\right.$ February) is 0.75 (Fig.8). The limited protective role of the vegetation is interpreted additionally to the time that the incident was occurred, period with the smallest rates of evaporation and the time of vegetation tranquility from the height of the rainfall, the previous days, fact that significantly confined the soil's water capacity and of course, from the long duration and intensity of the rare rainfall of 10 February 2010.

The rainfall of February $10^{\text {th }}, 2010$, was of extreme intensity. Particularly during the torrent in Argiro (2), the diversion capacity of the torrent-bed was not sufficient for the evacuation of the flood peak. Moreover, the anthropogenic interference resulted in the minimization of the stream-bed cross section that in its turn aggravated the situation. As far as the flood under study is concerned, it should be mentioned that the problem of sedimentation was very intense. Materials of various diameters, drifted away from the mainstream and banks of the torrent, were transported through the bed downhill. The above materials were deposited in the village, where the slope is minimized, and thus resulted in the reduction of the diversion capacity of the stream and the overflowing.

No works of adjustment were foreseen or carried out in these torrents. The complacency that derives from the small size of the watersheds of the ephemeral currents if the main cause to these cases for not taking any protective measures. Especially for the torrent currents that pass through the residential areas would investigate all the possible scenarios for the hazard of flood. If we have ungauged catchments with available only rainfall data the secure solution comes from the use of the synthetic unit hydrograph. As it was also occurred from the results of the present report, the use of the flood hydrographs can lead to secure estimation of the maximum peak discharge which is necessary for the methodology of dimensioning of the adjustment works.

An effective study of flooding phenomena requires the existence of a mainstream of appropriate dimensions. That can be achieved by using the Forest Techniques System of torrent control. This system includes technical and rural infrastructure as well as planting infrastructure. As far as the plain parts of the torrential streams are concerned, the method includes constructions of dikes in connection to stonework constructions of sills.

\section{Conclusions}

The present study led a number of conclusions briefly presented below.

(a) The rain fall in the area was a rare rainfall event with a return period over 200 years.

(b) In such intense rainfall events, the contribution of forest coverage of the watershed to smoothing of peak flows is limited.

(c) The runoff coefficient for the particular area and the prevailing vegetation conditions, reached a great magnitude.

(d) The heavy rainfall was the triggering factor for the debris flow in the torrent Argiro (2).

(e) The method of the Synthetic Unit Hydrograph seems to be efficiently applicable to the watersheds of torrents of the Mediterranean countries for the determination of flood hydrographs with the condition that results are validated.

(f) The possibility of flood danger should always be examined, protective measures against floods should be taken in torrential currents that pass through residential areas regardless the size of the watershed and the presence or not of the protective forest coverage.

It is hoped that the results of this study will be of use in improving our prediction to support flood mitigation activities from government agencies.

\section{REFERENCES}

Ahrens, D. (1994), Meteorology Today. West Publishing Company. New York. 
Anderson H., Hoover M. and Reinhart K. (1976), USDA Forest Service. General Technical Report, PSW- 1811976.

Arthur G. and Cudworth Jr. (1987), The deterministic approach to inflow design rainflood development as applied by the U.S. Bureau of Reclamation, Journal of Hydrology, 96, 293-304.

Aulitzky H. (1985), Torrent Erosion in Austria caused by natural Conditions, Proceedings International Symposium Erosion, Debris Flow and Prevention, Tsukyba, Japan, 167-172.

Camarasa Belmonte A.M. and Segura Beltran F. (2001), Flood events in Mediterranean ephemeral streams ramblas/ in Valencia region, Spain, Catena, 45, 229-249.

Chow V.T., Maidment D. and Mayes L. (1988), Applied Hydrology, Mc Graw International Editions, 1-572.

Chow V.T. (1964), Handbook of applied Hydrology, section 14. Mc Graw - Hill Book Company. New York, 1-54.

Daniil E., Michas S. and Lazaridis L. (2005), Hydrological modeling for the determination of design discharges in ungauged basins, Global NEST Journal, 7(3), 296-305.

Dhar N.O. and Nandargy S. (2003), Hydrometeorological aspects of floods in India, Natural Hazards, 28, 1-33.

EEA (European Environment Agency) (2004), Impacts for Europe's changing climate. An indicator basedassessment, EEA Technical Report №2, Copenhagen.

http://reports.eea.europa.eu/climate_report_2_2004/en/impacts_of_europes_changing_climate.pdf

Fotakis D., Sidiropoulos E. and Loukas A. (2007), Integration of a hydrological model within a Geographical Information System: Application to Yermasogia, Cyprus, Environmental Management and Engineering, Planning and Economics, 203-208.

Gaumea E., Livetb M., Desbordesc M. and Villeneuved J.P. (2004), Hydrological analysis of the river Aude, France, flash flood on 12 and 13 November 1999, Journal of Hydrology, 286, 135-154.

Georgiou P., Papamichail D. and Karamouzis D. (2003), Comparative analysis of the peak flows estimates with synthetic unit hydrographs procedures and empirical formulas. Proceedings of $3^{\text {rd }}$ National Congress Agriculture Engineering, Thessaloniki, Greece, 11-19 (in Greek).

Hibbert A.R. (1971), Increases in streamflow after converting chaparral to grass, Water Resources Research, 7, 71-80.

Hisdal H., Stahl K., Tallaksen L.M. and Demuth S. (2001), Have streamflow droughts in Europe become more severe or frequent?, International Journal of Climatology, 21(3), 317-333.

Hooke J.M. (2006), Human impacts on fluvial systems in the Mediterranean region, Geomorphology, 79(3-4), 311-335.

Iglesias A., Garrote L., Flores F. and Moneo M. (2007), Challenges to Manage the Risk of Water Scarcity and Climate Change in the Mediterranean, Water Resources Management, 21, 775-788, doi: 10.1007/s11269-006-9111-6.

Jain K., Singh R. and Seth S. (2000), Design Flood Estimation Using GIS Supported GIUH Approach, Water Resources Management, 14, 369-376.

Kotoulas D. (1980a), Torrential floods in Greece and human influence, Proceedings of the $2^{\text {nd }}$ Pan Hellenic Congress of Hydrology, 185-196 (in Greek).

Kotoulas D. (1980b), Materialerzeugung und Murenbildung dargestellt am Beispiel einiger murfahiger Wildbache Nordgriechenlands. Internationales Symposion, Interpraevent, Bad Ischl: 331-350.

Kotoulas D. (2001), Management and control of torrents. Part I. Aristotle University Press, Thessaloniki (in Greek).

Kumar R., Chatterjee C., Singh R., Lohani A. and Kumar S. (2007), Runoff estimation for an ungauged catchment using geomorphological instantaneous unit hydrograph (GIUH) models, Hydrological Processes, 21, 1829-1840.

Linsley R.K., Kohler M.A. and Paulhus H.L. (1975), Hydrology for Engineers. $2^{\text {nd }}$ Edition, 1-482.

Loukas A., Quick M. and Russell S. (1996), A Physically Based Stochastic-Deterministic Procedure for the Estimation of Flood Frequency, Water Resources Management, 10, 415-437.

Muzik, I. (1992), Derivation of unit and flood hydrographs using a GIS, Environmental Monitoring and Assessment, 23(1-3),45-56, DOI: 10.1007/BF00406951.

Myronidis D., Emmanouloudis D., Stathis D. and Stefanidis P. (2009), Integrated flood risk mapping in the framework of E.U. directive on the assessment and management of flood risks, Fresenius Environmental Bulletin, 18(1),102-111. 
Myronidis D., Stefanidis P. and Fotakis D. (2010), Quantitative estimation of a watershed 50-year peak flood discharge by building a custom GIS application, Journal of Environmental Protection and Ecology, Book 3, 11:1193-1192.

Papamichail D., Georgiou P. and Karamouzis D. (2001), Estimation of flood hydrographs for the 7-8 October high rainfall in Megali Panagia Chalkidikis area, Hydrotechnika, 11, 47-60.

Papamichail D. (2001), Applied surface hydrology. Giahoudi - Giapouli, Thessaloniki 1-394 (in Greek).

Qi S., Wang Y., Sun G., Xiao Y., Zhu J., Yang H., Hu X., Wu B., Wang Y. and McNulty S. (2009), Effects of Forest Composition and Spatial Patterns on Storm Flows of a Small Watershed, Journal of the American Water Resources Association (JAWRA), 45(5),1142-1154, DOI: 10.1111/j.1752-1688.2009.00350.x.

Sapountzis M., Papathanasiou Th., Myronidis D. and Aggelakopoulos J. (2007), Hydrological response of torrent Gerampini in Zagora after the construction of check dams, Hydrotechnika, 17, 89-104.

Schilling M. (1997), Increase in flood risk due to bedload- Examples from the Alps, International Journal of Sediment Research, 12(3),161-169.

Scott D.F. and Lesch W. (1997), Streamflow responses to afforestation with Eucalyptus grandis and Pinus patula and to felling in the Mokobulaan experimental catchments, South Africa, Journal of Hydrology, 199, 360-377.

SCS (Soil Conservation Service) (1972), National Engineering Handbook. Section 4, U.S. Department of Agriculture, Washington, DC.

Serrano-Muela M.P., Lana-Renault N., Nadal-Romero E., Regüés D., Latron J., Martí-Bono C. and García-Ruiz J.M. (2008), Forests and Their Hydrological Effects in Mediterranean Mountains The Case of the Central Spanish Pyrenees, Mountain Research and Development, 28(3/4),279-285, DOI:10.1659/mrd.0876.

Shaw E. (1993), Hydrology in practice. Chapman and Hall (Second Edition), 539p.

Sofios S., Arabatzis G. and Baltas E. (2008), Policy for management of water resources in Greece, Environmentalist, 28, 85-194, DOI 10.1007/s10669-007-9126-4.

Stathis D., Sapountzis M. and Myronidis D. (2010), Assessment of land use change effect on a design storm hydrograph using the SCS curve number method, Fresenius Environmental Bulletin, 19(9a),1928-1934.

Stathis D. and Sapountzis M. (2003), Investigation of the relation between rainfall and runoff in the watershed of torrent Petrenia (Gomati region, Chalkidiki, northern Greece) after the storm of 7-9 $9^{\text {th }}$ October 2000, Geotechnical scientific issues, 13(1),69-78.

Stefanidis P., Kalinderis I. and Tziaftani F. (2007), The cause and the mechanism of the $7-8$ October 2006 flood at Olympiada Chalkidiki (north Greece). International Conference Erosion and Torrent Control as a Factor in Sustainable River Basin Management, Belgrade - Serbia, 1-8.

Stefanidis P. (1995a), Exploring the causes and mechanisms of floods in Greece. Proceedings of the International Symposium "Protective and environmental management of watercourses" Ministry of Environment, Athens, 139-140 (in Greek).

Stefanidis P. (1995b), The cause and the mechanism of the debris flow in Brasna and Asprovalta, North Greece. Scientific Conference with Participation of Foreign Specialists "90 Years of soil Erosion Control in Bulgaria" Sofia, 30-36.

Stefanidis P. and Kotoulas K. (1992), Erosionsbeschleunigung nach den Waldbranden in Griechenland, Internationales Symposion, Interpraevent, Tagungspublikation 1:365-376.

Tsakiris G. (1995), Technical hydrology. Simetria, Athens, 671pages (in Greek)

USDI (US Department of the Interior Bureau of Reclamation) (1987), Design of Small Dams, Water Resources Technical Publication. $3^{\text {rd }}$ edition, US Government Printing Office, 23-57.

White S., García-Ruiz J.M., Martí-Bono C., Valero B., Errea M.P. and Gómez-Villar A. (1997), The 1996 Biescas campsite disaster in the Central Spanish Pyrenees, and its temporal and spatial context, Hydrological Processes, 11,1797-1812. 